\title{
Making Sense of the Yoruba Littoral
}

\author{
Ayodeji Olukoju \\ University of Lagos, Nigeria \\ aolukoju2002@yahoo.com
}

\begin{abstract}
This article examines the Yoruba coast in its local and global settings. Drawing on the work by Michael Pearson, the article argues that the Yoruba littoral is by no means a monolithic community in cultural, religious and economic terms. It points out that while most Yoruba define themselves in relation to fixed settlements in the hinterland, the littoral is defined by high mobility and flexibility that stretch far beyond the boundaries associated, in the widest sense, with the Yoruba.
\end{abstract}

"[S]tudies of the littoral can contribute importantly as we try to write not only maritime, but also world, history."

Michael N. Pearson, $2006^{1}$

\section{Ecology as Matrix, Setting and Framework}

Coastal Yorubaland is a community of communities, with identifiable local peculiarities and sub-regions. Lying between Latitudes $6^{\circ}$ and $6^{\circ} 30^{\prime} \mathrm{N}$ and Longitude $2^{\circ} 3^{\prime}$ and $6^{\circ} \mathrm{E}$, it occupies the 800-kilometre stretch from Badagry in the west to the eastern extremity of Ilajeland to the east. ${ }^{2}$ The Yoruba coast comprises the southern parts of modern Lagos, Ogun and Ondo States, and insofar as it includes non-Yoruba migrants, a large hinterland of speakers of Ijaw, Urhobo, Bini and other languages, and eventually Itsekiri territory in Delta State, it must actually be considered as multi-ethnic.

1. Michael N. Pearson, "Littoral Society: The Concept and the Problems," Journal of World History, 7.4 (2006): 373.

2. R.O. Ajetunmobi, "Theories and Concepts in Migration and Settlement Studies: The Case of the Coastal Yoruba," The Social Sciences, 7.2 (2012): 289. 
The ecology of coastal Yorubaland is expectedly diverse in terms of topography, flora and fauna. The zone is traversed by an intricate creek-river-lagoon network, which has been a longstanding highway of interconnectedness in an open terrain. The water-based highway was thus a bridge, rather than a barrier, between contiguous and distant communities. The range of occupational specializations - seafaring, fishing, salt-making and boat-making - reflects adaptation to and mastery of the ecological setting. The zone has notable nodes (Badagry, Lagos, Epe, Ejinrin, Atijere, Igbokoda, etc.) as staging posts of commerce and exchange of technology of fishing and fish processing.

The Yoruba littoral has also been at the receiving end of coastal erosion, which has devastated several communities. Specialist studies, including a recent $\mathrm{PhD}$ thesis, have highlighted the impact of this threat to the livelihoods of the people of the Western Niger Delta, of which the Ilaje coastline is a part. ${ }^{3}$ Though focused on the two local governments of Ilaje and Ese-Odo in Ondo State, the research findings are broadly applicable to other parts of coastal Yorubaland. The study reveals the alarming extent to which seawater had polluted the potable water sources of the people. Eighty percent of the two focal communities in the study area complained about the salinity of their local water supply, and an equal percentage also reportedly suffered from various water-related ailments. A similarly high percentage of persons too have had to relocate to safe and higher ground as their homes had been eroded away by sea waves. The people have accordingly suffered great economic losses in their farming and fishing enterprises. Indeed, a large number of people in the affected communities simply turned to other economic enterprises for survival.

Along this littoral are clusters of related communities: the Ikorodu; Epe/ Ejirin; Ijebu Waterside; and the Ikale/Ilaje axes, tapering into Itsekiriland, with their interlinked histories, livelihoods and sociocultural relations between each other and to neighboring communities. But, before delving into that subject matter, we need to engage with the concept of the littoral.

\section{The Littoral, Its Drivers and Dynamics}

The concept of "littoral" or "coast" underpins the discussion in this article. One scholar who has devoted much effort to unravelling the internal dynamics of littoral society is Michael Pearson, author of two seminal articles on the

3. Oluwaseun Love Odidi, "Coastal erosion and its socio-economic impact on the people of Western Niger Delta Area, Nigeria," (PhD Thesis, Federal University of Agriculture, Abeokuta, July 2012). See also, Olukoju, "Nigeria's Coastal Zone: Environmental Problems, Responses, and Suggested Remedies," in Akinjide Osuntokun (ed.), Dimensions of Environmental Problems in Nigeria, Ibadan: Davidson Press, 1997, 69-84. 
subject. ${ }^{4}$ In the first, path-breaking publication, he defined "littoral" as the "land located on the seashore, or that part of the land which is influenced by the sea." 5 In a second piece, he re-stated the definition of the littoral as "the coastal zone, the beach, and some indeterminate frontier on land." ${ }^{\text {As helpful }}$ as they are, these definitions mask the great diversity of the concept in its local settings. For, in addition to common features, there are local peculiarities of littoral communities all over the world. To be fair, Pearson himself stressed the imperative of analyzing the ramifications of "land-sea divisions and the nature of littoral society."7 In this context, he emphasized location, culture and occupation as the drivers of littoral society. ${ }^{8}$ Although his analysis was informed by Asian, especially Indian, maritime history, he highlighted the following striking features of the generic littoral, which are worthy of consideration.

First, he posited that, as land and sea "intertwine in complex and various ways," the two elements exist as "integral parts" of a "continuum." Pearson explained further that littoral and the interior are "different, but complementary." This "complementarity between the littoral and the hinterland" is predicated on the porosity of the coastal frontier. Indeed, he argued that there is actually "no clear line of demarcation. Rather, there is a continuum between land and sea activities, with the strip of the littoral in the middle, acting as a hinge or mediator. There is no dichotomy, the two are not discrete. Rather they merge and blend in the littoral." In support of this position, he cited the declaration by Jan Heesterman that the littoral as a frontier zone does not "separate or enclose," but "rather finds its meaning in its permeability." 10 The permeability of the zone, Pearson stressed, underlines its "amphibious" character as it moves "easily between land and sea."

Second, Pearson stressed the influence of geography on littoral societies. The differential configuration of their hinterlands means that the inland depth of each littoral zone varies one from another. In western India, for example, the western Ghats, a craggy mountain chain, practically cuts the littoral from the hinterland. In contrast, there is no physical barrier between the coast and the hinterland in western Nigeria.

4. M.N. Pearson, "Littoral Society: The Case for the Coast," The Great Circle: Journal of the Australian Association for Maritime History, vol. 7, no. 1, 1985, pp. 1-8; and Pearson, "Littoral Society: The Concept and the Problems," 353-373.

5. Pearson, "Littoral Society: The Case for the Coast,", 1.

6. Pearson, "Littoral Society: The Concept and the Problems," 354.

7. Pearson, "Littoral Society: The Case for the Coast," 3.

8. Pearson, "Littoral Society: The Concept and the Problems," 356.

9. Pearson, "Littoral Society: The Case for the Coast," 4.

10. Pearson, "Littoral Society: The Concept and the Problems," 356, citing J.C. Heesterman, "Littoral et Interieur de l"Inde," Itinerario, 1 (1980): 89. 
Third, the land-sea frontier is "flexible, variable," creating, in Braudelian terms, "a thousand frontiers indeed!"11 Pearson pointed out that not all littoral societies have beaches. Where the coast is a delta, there is "ambiguity, lack of definition and boundaries, a zone where land and sea intertwine and merge, really the fungibility, the interchangeability, of land and sea." ${ }^{2}$

Fourth, the sea is the focus of littoral society as the lives of its inhabitants are "connected with the sea," but their history is "not restricted to the sea." This is because their society is open to influences from far distant places in the hinterland..$^{13}$

Fifth, littoral society is a product of interactions between land and sea, and concurrent influences from both sources: "no one lives totally on the water and completely uninfluenced by the land." ${ }^{4}$ This is vividly portrayed by the occupational specialization of the archetypal littoral family: "a fishing family essentially links land and sea, with the woman on the former and the men on the former."15 This contrasts with the lifestyle of peasants, who are tied to the land.

Sixth, the boundary between littoral and hinterland is at a point "when a land activity is in no way influenced by the sea." Pearson described this as "the land frontier, the end of the littoral." ${ }^{16}$ Maritime influence varies widely but is generally "stronger (though not uniformly) on the coast, and decreases as one moves inland."

Seventh, littoral society is more pluralistic than the hinterland because of the diversity of groups drawn to it. Eighth, fishing is at the heart of the economic enterprise and diet of littoral peoples. "Fisherfolk," Pearson contended, "are indeed the quintessential littoral people." ${ }^{17}$ More fish is eaten in the littoral zone per capita than is the case in the hinterland. Finally, in many cases, trade and production in littoral society are targeted at 'much more distant and "foreign" markets than is an inland area. ${ }^{18}$

These generalizations are not uniformly applicable to all littoral societies the world over. Moreover, over the past two centuries, littoral society in the Global South has been transformed by the interplay of internal developments

\footnotetext{
11. Pearson, "Littoral Society: The Case for the Coast," 6.

12. Pearson, "Littoral Society: The Concept and the Problems," 355.

13. Pearson, "Littoral Society: The Case for the Coast," 6.

14. Ibid.

15. Pearson, "Littoral Society: The Concept and the Problems," 360.

16. Pearson, "Littoral Society: The Case for the Coast," 6.

17. Pearson, "Littoral Society: The Concept and the Problems," 360.

18. Pearson, "Littoral Society: The Case for the Coast," 6-7.
} 
and global dynamics - imperialism, industrialisation and globalization. ${ }^{19}$ The foregoing analysis is useful as a background for examining littoral Yorubaland across space and time. We shall see the extent to which coastal Yorubaland conforms to these generalizations.

\section{The Yoruba and the Sea: Riparian Landlubbers?}

The concept of the littoral or seascape is much more than a spatial construct. It is, therefore, important to know how the littoral people define themselves, shape their societal world view and earn their livelihoods in relation to it. An interesting comparative perspective is provided by the Swahili of eastern Africa. It is established in the literature that the Swahili identity evolved, not just in terms of the admixture of races and cultures, but also in the context of their location and occupation. Hence, the word "Swahili" itself means "shorefolk." Randall Pouwels described Swahili culture as "a child of its human and physical environment, being neither wholly 'African' nor 'Arab,' but distinctly 'coastal', the whole being greater than the sum of its parts." ${ }^{20}$ Accordingly, in terms of location, occupation and culture, we shall explore the place of the sea and "coast" or "littoral" in Yoruba cosmology.

Specifically, we shall consider the Yoruba register for sea(scape). This is represented in "okun" (sea) ${ }^{21}$, "bebe okun" (the seashore), "osa" (lagoon) and its derivative, "langbasa"22 (indicative of the vastness of the lagoon), "ebute" (wharf) and "eseodo" (riparian or riverine). The Yoruba clearly distinguish the sea from the lagoon, classifying the former as vastly superior. A Yoruba expression states that: "Okun ni olori omi, osa ni Baale odo," meaning "the sea is the head of all water bodies, the lagoon is the chief of the ponds." ${ }^{23}$ This ranking is justified in a related Yoruba expression: "Gbogbo omi nii dori kodo f'Olokun, gbogbo odo kodo nii dori kodo f'Olosa," 24 meaning that while rivers and their tributaries ultimately end up in the lagoon, the lagoon itself "defers"

19. Pearson concedes this point in "Littoral Society: The Concept and the Problems," 367.

20. Randall L. Pouwels, Horn and Crescent: Cultural Change and Traditional Islam on the East African Coast, 800-1900, Cambridge: Cambridge University Press, 1987, 31, cited in Pearson, "Littoral Society: The Concept and the Problems," 357.

21. The Bini also call the sea, "okun."

22. Incidentally, this is the title of the journal of Yoruba Studies in the Faculty of Arts, University of Lagos, Nigeria. Langbasa is actually a settlement on the Lagos lagoon.

23. Kolawole Ademola Oluwasiku, "Odun Olokun ni Ilu Eko," ["The Olokun Festival in Lagos"] (B.A. Research Project, University of Lagos, 1990), 34. I thank Dimeji Ajikobi, senior lecturer, and Yoruba language and culture specialist, University of Lagos for drawing my attention to this source.

24. Oluwasiku, “Odun Olokun ni Ilu Eko," 35. 
to the sea. The clearest association of the Yoruba with the sea is indicated by the deity, Olokun (Lord of the Sea) ${ }^{25}$ and Yemoja (the sea goddess), rituals and festivals in whose honour are performed by the Yoruba till today. The iconic "Ori Olokun" mask is the most famous cultural artifact and mascot of the Yoruba, but the Olokun deity itself is not a cultural monopoly of the Yoruba. Olokun is entrenched in the religious and cultural systems of the Benin and Agbor communities in Edo and Delta States, respectively. ${ }^{26}$ It has been suggested that the etymology of Yemoja indicates a connection with the Oya (Niger) river, rather than the sea. ${ }^{27}$ This implies that the northern Yoruba took the apparently flooded river as representative of the sea, which was actually located several hundred kilometres to the south.

Another issue worth exploring is the importance of the coastal zone, in terms of its geographic expanse, relative to the entire Yoruba territory: how it has contributed to shaping the overall or, even, regional, history of the Yoruba. In other words, we need to establish the relative contribution of internal and external (sea-induced) dynamics in the making of the Yoruba throughout their history. Given that the Yoruba are known for their urban agglomerations right from precolonial times, it may be useful to ascertain the degree to which the sea or lack of access to it has shaped urbanization in Yorubaland before colonial rule. We can gauge this by the number and sizes of urban centres outside Lagos. The discussion can be enriched by incorporating other dynamics, such as the role of British colonial rule, formal education, and modern transport and economic systems in effecting a shift, and to what extent, in terms of population and political influence.

On the basis of current knowledge, it is safe to declare the historic marginality of the littoral in the overall Yoruba landscape. ${ }^{28}$ In short, the Yoruba are landlubbers! They are, at best, a riparian, but not a maritime, people. This point is driven home by a striking comment by Dr. Omolere Ehinmore in a publication on the Ilaje-Izon (Ijo, Ijaw) war of 1998-99. He noted that, while the Izon could mobilize support from their kinsmen in Bayelsa, Rivers and Delta States, the Ugbo-Ilaje, who bore the brunt of Izon attacks, "were sup-

25. Ibid, 29, states that Olokun is the Yoruba equivalent of the Greek goddess, Neptune.

26. Ibid., 57.

27. "The Yorubas and the Sea," retrieved on 2 December 2016, http://blackhistory.50webs.com/africanmaritimehistory/The_Yorubas_and_the_Sea.pdf.

28. Littoral Yorubaland communities, outside Lagos and Badagry, are marginal to mainstream Yoruba historiography, perhaps because of being far removed from the centres of military and political activities and mega-state formation up to the onset of British colonial rule. The subordination of Epe, Ejinrin and Ikorodu, to either the Ijebu Kingdom or Lagos, is symptomatic of the marginality of the zone relative to the political powers in its hinterland. 
ported only by their kinsmen in the Ilaje coastal communities since other Yoruba groups are not skillful in naval belligerency." ${ }^{29}$

Accordingly, Yoruba water-related economy and worldview centre on their rivers. Though only a few of them - Osun, Ogun, Oba and Oya - are navigable, rivers have played key roles in the evolution of Yoruba society and economy. The people commuted on the rivers, especially the Ogun, and built religious and communal myths around them. Indeed, people attribute the founding or defence of their communities to such rivers. Iwo town in Osun State provides a paradoxical example. It is associated with the Oba river, even in its oriki, but it is located in Osun State, belying the Yoruba aphorism that "a kii gbomo Oba f'Osun" (literally, "You do not ascribe the paternity of Oba's children to Osun"). Odo Oya (River Niger), though no longer contiguous to mainland Yorubaland featured prominently in (northern) Yoruba myths and legends. In effect, the bulk of the Yoruba population has traditionally been excluded from the sea. Their limitation to the rivers and lagoons is reflected in the small size and lack of sophistication of their water craft. Another indication is that, with the exception of the Ilaje, the Yoruba lack a seafaring culture, such as is found among the Kru of Liberia. In this regard, it may be speculated that a people's relationship with the sea is largely determined by what they take it to be. If it is seen as a resource and source of survival in a resource-deficient territory, they exploit it for its food and other resources. If the sea is regarded as a highway, they invent watercraft with which to commute on it. However, if the sea is perceived as a source of potential calamity or fear, the people might develop festivals and other social and religious activities to propitiate the angry waves, and might be too fearful to venture out to sea. According to Robert Smith, eighteenth-century British ship captains claimed that precolonial Nigerians were too scared of the sea to venture into it. ${ }^{30}$

It may be noted that, for the Yoruba, Olokun is not only Lord of the Sea, but Lord of Trade. This clearly associates the sea with commercial enterprise and wealth. It may be speculated whether the trade in question was the trans-Atlantic slave trade or the trade in Ijebu cloth, which passed through the Benin port of Ughoton, that preceded it. Seaborne trade would definitely have played a major role in the wealth that underpinned the grandeur of ancient Ife, as revealed in the artifacts of that ancient civilization. The non-African origins of some of the materials found on site suggest this maritime connection.

29. Omolere Ehinmore, "Boundary Conflict and Security Challenges in the Western Coast of the Niger Delta: The Ilaje-Ijo War Factor, 1998-99," International Journal of Humanities and Social Science, 4.8 (2014): 281. Italics added for emphasis.

30. Robert Smith, “The Canoe in West African History," Journal of African History, 11.3 (1970): 515-533. 
That said, it was only in colonial Lagos that the Yoruba engaged with the sea as actors and subjects, and not merely as objects of history. Profiles of leading Lagos/Yoruba merchants of the mid-nineteenth century to the 1920s in Lagos can be found in the Red Book of West Africa, ${ }^{31}$ and other studies have examined individual personalities. ${ }^{32}$ However, the notable Lagos/Yoruba name in the foreign shipping sector was Captain James Pinson Labulo ("J.P.L.") Davies, the subject of a biography by a notable surgeon and amateur historian. ${ }^{33}$ Fragments of his maritime exploits, including owning and captaining his own seagoing vessels, contained in the Herbert Macaulay Papers, have been highlighted in a publication on shipping in Lagos. ${ }^{34}$

\section{Ayelujara: Metaphor of Interconnectedness in Littoral Yorubaland}

Modern Yoruba people refer to the internet as "ayelujara," connoting the seamlessness of technology-based interactions in the globalized world in which we live. However, the word, "ayelujara," in its original usage was coined in the late 1920s to refer to one of the colonial-era alloy coins. It will be recalled that the inter-war period was turbulent in Lagos and the hinterland, especially following the demonetization of precolonial currencies and the introduction by fiat of silver and alloy coinage, and, more controversially, currency notes. ${ }^{35}$ One of those coins, a nickel penny, had a hole bored in the middle of it so that colonial peoples could string them together for easy portability. It was this

31. The full reference is Allister Macmillan, The Red Book of West Africa (London, 1920, reprinted by Spectrum Publishers, 1993).

32. Kristin Mann, "The Rise of Taiwo Olowo: Law, Accumulation and Mobility in Early Colonial Lagos," in Richard Roberts and Kristin Mann (eds.), Law in Colonial Africa, (Portsmouth, NH: Heinemann), 85-102; and the multiple biographies in Antony G. Hopkins, "Innovation in a Colonial Context: African Origins of the Nigerian Cocoa-Farming Industry, 1880-1920," in Clive Dewey and A.G. Hopkins, The Imperial Impact: Studies in the Economic History of Africa and India (London: The Athlone Press, 1978), 83-96; and Ayodeji Olukoju, "Accumulation and Conspicuous Consumption: The Poverty of Entrepreneurship in Western Nigeria, ca. 1850-1930," in Emmanuel Akyeampong, Robert Bates, Nathan Nunn \& James A. Robinson, eds., Africa's Development in Historical Perspective (Cambridge: Cambridge University Press, 2014), 208-30.

33. Adeyemo Elebute, The Life of James Pinson Labulo Davies: A Colossus of Victorian Lagos, (Lagos: Prestige, 2013).

34. Ayodeji Olukoju, "Elder Dempster and the Shipping Trade of Nigeria During the First World War," Journal of African History, 33.2 (1992): 255-271.

35. I have engaged with this topic in Ayodeji Olukoju, "Nigeria's Colonial Government, Commercial Banks and the Currency Crisis of 1916-1920," International Journal of African Historical Studies, 30.2 (1997): 277-298. 
hole that gave that coin the appellation of "ayelujara." A Lagos newspaper reported that: "The Yoruba called the Nigerian nickel pennies "Aiyelujara." 36

As we shall demonstrate in this essay, "ayelujara" graphically conveys the seamlessness of inter-group relations and the possibility of multiple identities along the Yoruba littoral. There has been, until recent times, the lack of fixed boundaries ${ }^{37}$ to, and a complement of, peaceful socio-economic exchanges. In this regard, the ayelujara coin, metaphorically represents for us today money in both its social and economic meanings. ${ }^{38}$ In a local setting ayelujara conveys the impression of a "global village" in microcosm. Yet, communities have set boundaries, which are both fixed and shifting, subject to setting and re-definition. A notable instance of this is the exercise of fishing rights in intra- and inter-communal settings. Ayelujara is thus a marker of, and a metaphor for, mobility, the transfer and exchange of value, within, between and beyond communities in the Yoruba littoral. This is illustrated by the circulation of money and socio-cultural ideas, two elements which defy rigid boundaries, a key feature of life in the littoral. It has been noted, for example, that "a variant of Yoruba uniform culture among most Ilaje, Ijebu and Awori settlements" characterizes coastal Yorubaland. The shared cultural institutions and cultural practices include "institution of Obaship and palace organization, festivals and ritual practices." These institutions and practices - beaded crowns, white caps and other paraphernalia of office - were presumably introduced to the region by migrants from Ile-Ife, Benin and some hinterland Yoruba towns. ${ }^{39}$ Peoples of the littoral also relied on divination in the establishment of their early settlements. $^{40}$

Identity formation is another feature of the interconnectedness symbolized by the metaphor of "ayelujara." The dynamics of migrations, economic enterprise, war and peace, and cultural exchanges have led to a recurring definition and self-definition of self and the other in the Yoruba littoral. Scholars of migrations and settlement in littoral Yorubaland and adjoining places have buttressed these assertions. ${ }^{41}$ Koya Ogen's research has demonstrated the diversity

36. Nigerian Pioneer, 25 October 1929, Random Notes and News.

37. Ehinmore, "Boundary Conflicts and Security Challenges," 282, partly blames the "costly error of non-proper demarcation" of boundaries between Ilaje and Izon by the British and subsequent rulers of Nigeria for the war of 1998-99.

38. Toyin Falola and Akanmu Adebayo, Culture, Politics and Money Among the Yoruba (New Brunswick: Transaction Publishers, 2000).

39. Ajetunmobi, “Theories and Concepts in Migration," 295.

40. Ibid, 295-296.

41. Ibid, 289-296; R. O. Ajetunmobi, Coastal Yorubaland of Nigeria, 1500-1900: Migrations, Settlements and Socio-political Development, Lagos: Raytel Communications, 2003; and Olukoya Ogen, "The Akoko-Ikale: A Revision of Colonial Historiography on the Con- 
Ayodeji Olukoju

of origins of littoral peoples and a bewildering dispersion of the sources of their secondary migrations. But for his seminal article, it would have been difficult to establish any affinity between the coastal Ikale and the upland Akoko-Yoruba. This calls for further reflections on the peopling of the zone. First, we need to adopt an elastic definition of the peoples of this zone to embrace both Yoruba and Yoruboid peoples. Second, it is imperative to recognize the complexity of inter-group relations along the coast.

In this connection, we may note that movements and interactions in this zone are not only lateral, taking place along the coast, but also vertical in relation to the hinterland. ${ }^{42}$ Vertical or north-south movements, perhaps much more the lateral, indicate the complementarity of the economies and material needs of the littoral Yoruba and their hinterland neighbours. Ecology plays a critical role of occupational specialization such that coastal fisherfolk complement the arable farmers of the hinterland. On the peopling of littoral Yorubaland, it is clear that we have a spectrum of Yoruba, Yoruboid, Edoid, Ogu and other peoples along the coastline. Each deserves attention but all should be considered as elements of a community shaped by its internal dynamics and open to external influences.

Regarding the lateral and vertical dimensions of inter-group relations, the concomitant power relations between proximate and distant neighbours, commercial enterprise, oracular and religious activities are critical to the daily lives of the people. In that sense, we should identify and analyze hierarchies of power relationships, especially between political and economic nodes, ${ }^{43}$ on the one hand, and their satellites, on the other. For example, as Olubomehin has demonstrated, Ejinrin was the major port of the Ijebu Kingdom, in which the Awujale's liaison officer, one Mr. Turner, was stationed to protect his fiscal and commercial interests. ${ }^{44}$ The same can be said of Benin and Ondo, two powerful kingdoms in the immediate hinterland of the eastern end of the Yoruba litto-

struction of Ethnic Identity in Southeastern Yorubaland," History in Africa, 34 (2007): 251271.

42. Ayodeji Olukoju, "The Politics of Free Trade Between Lagos and the Hinterland, 1861-1907," in Ade Adefuye, Babatunde Agiri and Jide Osuntokun, eds., History of the Peoples of Lagos State (Lagos: Literamed, 1987), 85-103.

43. Makun-Omi, was economically significant, but less so, politically: G.O. Ogunremi, "Makun-Omi (Ijebu Waterside): A Convergence of Economic Activities in the Nineteenth Century," mimeo.

44. Oladipo Olusola Olubomehin, "The Fluctuating Fortunes of Ejinrin Market in the Era of Yoruba Warfare, 1860-1892," Oye: Ogun Journal of Arts, III (1990): 128-135. The Awujale collected tolls and closed the market intermittently as the situation demanded as part of the power politics of the period, involving the British at Lagos and the hinterland Yoruba states, especially Ibadan. 
ral. Lagoon ports, such as Badagry, Epe and Ejinrin, played critical roles in lateral and vertical relations in southern Yorubaland. Olubomehin described Ejinrin and its market in the nineteenth century as "a strategic link between Lagos and the rest of the southeastern Yoruba hinterland." 45 Ejinrin was "a meeting point for other people from the lagoon settlements such as Epe, Atijere, Ode Ondo and others, where goods and services were exchanged and distributed." 46 It was an important feeder to the port of Lagos, which derived much of its produce for local consumption and export from the lagoon network in which Ejinrin was a major lynchpin. ${ }^{47}$

The history and peopling of Epe provide striking parallels. As noted by Siyan Oyeweso, Epe had been peopled in its formative years by "immigrant hunters, fishermen and political adventurers from Ile-Ife, Benin, Ilara, Ibeju and other outlying districts in the Epe region." ${ }^{48} \mathrm{He}$ added that the community received before 1900 "the influx of Ijo [Izon] and Ilaje from the waterside of Okitipupa Division and Mahin district of the defunct Ijo [Izon] Confederation." He stated that Izon fishermen settled with their wives, who "distinguished themselves in garri processing and the manufacturing of local gin; ogogoro." The Ilaje introduced Ayelala, a "social institution ... which performs a socio-judicial function in Epe as it is believed to have the special power of detecting and punishing evil doers." ${ }^{49}$ Although Epe people engage in other economic activities - farming (to produce cassava, rice and maize) and commerce, fishing has always been the defining economic enterprise. This is why the community is nicknamed "Epe Eleja" (Epe, the community of fishermen). The ancillary occupation of boat-building also thrives in Epe. Epe-made boats are utilized for deep-sea fishing and water transportation. ${ }^{50}$

In the same vein, it has been demonstrated that Badagry was not only important as an entrepôt of Lagos but was a node in the network of commercial and social relations between the coast and the Egbado hinterland. ${ }^{51}$ Badagry

45. Ibid, 128 .

46. Ibid. He noted (132) that traders from Ife, Oyo, Ilesha, Gbongan, Ado-Ekiti, Owo and Ilorin flocked to Ejinrin market after the British defeat of the Ijebu in 1892.

47. Ayodeji Olukoju, The Liverpool of West Africa: The Dynamics and Impact of Maritime Trade in Lagos, 1900-1950, (Trenton, NJ: Africa World Press, 2004).

48. Siyan Oyeweso, Journey From Epe: Biography of S.L. Edu, Lagos: West African Book Publishers Limited, 1996, 3, citing Ade Adefuye, "Lagoon Communities of Epe Division: Melting Pots of Culture," Journal of Business and Social Studies, n.s., 3.2 (1980): 140-55.

49. Oyeweso, Journey From Epe, 12.

50. Ibid, 3.

51. Ayodeji Olukoju, "Ecology and Economic Underdevelopment: Agriculture, Trade and Transport in Badagry, c.1880-1950," in G.O. Ogunremi, M. Opeloye and Siyan Oyeweso, eds., Badagry: A Study in the History, Culture and Traditions of an Ancient City (Ibadan: Rex Charles, 1994), 72-89. 
was a recurring factor in the Lagos chieftaincy politics during the nineteenth century. Hence, its depiction as "the traditional refuge of Lagosians" 52 fleeing political adversity. There are other examples of linkages with Benin, Ondo and Ife in the context of nineteenth-century Yoruba warfare and the spread of Christianity and cocoa-growing in Eastern Yorubaland. ${ }^{53}$

Physical contacts and social interconnectedness along the Yoruba littoral have bridged divides, bred stereotypes and defied barriers over the years. As might be expected, the stereotypes produced in the course of inter-group relations and identity configurations are often pejorative. For example, a middle-aged Ilaje man claimed in a private conversation with me that the Izon neighbours and historic enemies of the Ilaje "descended" from water hyacinth! He apparently found justification, as he explained it, in the fact that the Izon drift endlessly in one direction, never returning to their base! From at least the nineteenth century, peaceful relations between the Ilaje and Izon have been punctuated by wars, including a full-scale war in 1998-99. But, as noted by Ehinmore, there had been "inter-group relations between the two groups in the areas of trade, marriage and cultural diffusion for many years." ${ }^{54}$ In general, the relationship among the Ilaje, Izon and Itsekiri has been turbulent over the years. A graphic description of the state of affairs in the 1990s was provided by an Arogbo-Izon as follows: "an uneasy relationship with the Itsekiri, an unholy alliance and cultural romance with the Apoi and a confrontational relationship with the Ilaje." 55

However, others are more hilarious and self-deprecating than provocative. Thus, an Itsekiri man once related to me the popular saying among his people, presumably well known also among the Ilaje, that while the Ilaje are halfbaked ("ti o jolo") Ijebu, the Itsekiri were half-baked ("ti o jolo") Ilaje! ${ }^{56}$ This appears to be a hilarious way of explaining the close linguistic and cultural commonalities among the three groups, whose domains and migrations span the Yoruba littoral and beyond. What this indicates, however, is that communities along the littoral are products of overlapping migrations with their attendant traditions of origins and diversity of tongues. ${ }^{57}$

52. Oyeweso, Journey From Epe, 4.

53. S.A. Akintoye, "The Ondo Road Eastwards of Lagos, c.1870-95," Journal of African History, X.4 (1969): 581-598.

54. Ehinmore, "Boundary Conflict and Security Challenges," 278.

55. Donald K. Ojogo, "A Political History of the Arogbo-Izon of Ondo State, Precolonial Period to Present Times," (B.A. Research Project, University of Lagos, 1995), 26.

56. I owe this piece of information to Eyesan Kehinde Edremoda, a postgraduate student of the Department of History, University of Lagos, oral communication, 1996.

57. The linguistic affinity between the Itsekiri language on the one hand, and the Ondo and Ijebu dialects of Yoruba, on the other, has been established in Olufemi Akinkugbe, "A 
A major consequence of migrations is the phenomenon of colonies, settlements in diaspora by migrant fishermen and their families. The Ilaje are the best-known exemplars of this practice. Beyond their homeland in Ondo State, the Ilaje are found in significant numbers across the Lagos and Ogun coastline. All over the coastal plains of Lagos State, there are overlapping Ilaje, Izon and Ogu fishing settlements. The Ilaje at Bariga and in other parts of the Lagos metropolis are established indigenes with land rights acquired over decades of settlements, their Yoruba identity blending with that of their Awori hosts. In a significant incident in November 2016, the Ilaje in Lagos joined other indigenous communities to protest against the demolition of waterfront shanties in the state. The fact that even non-Yoruba-speaking Ogu and Izon are prominent along the Yoruba littoral lends credence to the multi-cultural character of that region of Yorubaland. The positive impact of non-indigenous migrants on the domestic economy is attested by the claim that the arrival of the Fante "boosted fishing" in Ijebu Waterside, while the arrival of the Keta (Ewe) and Ilaje had the same effect on Badagry. ${ }^{58}$

Ilaje fishing enterprise and extensive migrations eastwards of their homeland towards the Congo, westwards to as far as Senegal and southwards to Angola have been well documented in the literature. Their migrations have been described as "perhaps 'the greatest inter-regional movement in the modern history of the Yorubas." ${ }^{59}$ It has been stated that they are "always on the move...in search of fish." ${ }^{60}$ Ilaje fishing enterprise has tapped into innovations from external sources. As early as the 1930s, Ilaje fishermen learnt the "dogbo" method of trawling from Ijebu fishermen while their fellow Ilaje who returned from Gabon in the early 1970s introduced the "itahun," described as "a new method of fishing net floatation." ${ }^{11}$ However, the Ilaje of Bariga on the mainland of metropolitan Lagos have, since their initial settlement in the 1930s, deepened their fishing enterprise and diversified into wa-

Comparative Phonology of Yoruba Dialects, Igala and Itsekiri," (PhD thesis, University of Ibadan, 1978).

58. Adeola Abiodun Sanwo, "The History of Fishing Cooperatives in Badagry," (B.A. Research Project, University of Lagos, 1991), 86, cited in Olukoju, "Fishing, Migrations and Inter-group Relations," 72.

59. Meduoye Adebanjo Ola, "A History of Ugbo Kingdom from the Earliest Times to 1958," (B.A. Research Project, University of Lagos, 1995), 99, cited in Olukoju, "Fishing, Migrations and Inter-group Relations in the Gulf of Guinea (Atlantic Coast of West Africa) in the Nineteenth and Twentieth Centuries," Itinerario: European Journal of Overseas History, vol. 24, no. 2, 2000, 72 .

60. Olukoju, "Fishing, Migrations and Inter-group Relations," 70.

61. Omolere M. Ehinmore, "A History of Fishing in Ondo State, 1950-1997: A Case Study of the Ilaje Coastal Area," (M.A. Research Project, University of Lagos, 1998), 13, 33, 37. 
ter-related economic enterprises, such as the quarrying and sale of sand from the lagoon, lumbering and water transportation. But, while fishing is open to all without entry barriers, a few Ilaje dominate the other enterprises. The lumber merchants among them procure their logs from the forests of the Yoruba hinterland and float them down the rivers to Lagos. In all, Ilaje-Awori relations have been largely peaceful to the point that Ilaje have intermarried with them, and now allow their deceased members to be buried in Lagos, contrary to age-old practice. ${ }^{62}$

The idea of a Yoruba littoral commonwealth is real when a number of issues are considered. Among these are the degree of non-Yoruba elements registered in cultural borrowings and vice versa, the overlaps and blending in language registers, the similarity in songs and festivals, dress styles, family, personal and place names (though the same words might have different contextual meanings), and inter-ethnic marriages. The case of Okosi, an annual festival of rowing and sailing, is most striking. ${ }^{63}$ It involves a boat regatta and is associated with the appeasement of Olokun for greater catch, and safety for fishermen on the lagoons and the sea. As is well known, the religious and oracular network of Ayelala pervades and extends far beyond littoral Yorubaland. So fearsome is its reputation and so widespread its influence that it has been described as "a popular deity ... well known throughout the western part of Nigeria and beyond." ${ }^{4}$ That this is no spurious claim is buttressed by the fact that when Ayelala was invoked in the face of the looting of the burnt Oba market in Benin, the perpetrators speedily returned the looted items. Those who did not comply reportedly died mysteriously. ${ }^{65}$ The point to stress is that the reach of a deity that evolved in littoral Yorubaland, and is entrenched among the Ilaje and their Ikale neighbours, extends far beyond the immediate locality and, even, the cultural and geographical boundaries of Yorubaland.

62. Jimoh F. Wasiu, "A History of the Ilaje Settlement of Bariga, 1930-1989: A Socio-Political and Economic Survey," (B.A. Research Project, University of Lagos, 1993), 24, 27, 37, 41, cited in Olukoju, "Fishing, Migrations and Inter-group Relations," 79-80.

63. The Okosi festival is celebrated by Ijebu lagoon communities including Epe, Iwopin, Makun-Omi and Ode-Omi. See, for example, M. A. Odukoya, "Okosi Festival at Epe Town," Odu, 7, (1959): 28-30; and O. Ogunpolu, "Okosi Festival Songs," in Wande Abimbola, ed., Yoruba Traditional Festivals, (Ile-Ife: University of Ife Press, 1975), 551-598. A recent study is James Olusegun Adeyeri, "Socio-Economic Significance of Cultural Festivals in Epe Division of Lagos State: An Overview," International Journal of Research in Arts and Social Sciences, 4 (2012): 147-152.

64. Matthias Olufemi Dada Ojo, "Incorporation of Ayelala Traditional Religion into the Nigerian Criminal System: An Opinion Survey of Igbesa Community People in Ogun State," Issues in Ethnology and Anthropology, n.s., 9.4 (2014): 1001.

65. Ibid, 997. 


\section{Conclusion}

Making sense of the littoral in Yorubaland is not as straightforward as it appears. The exercise has two dimensions.

The first is the deconstruction of "Yoruba" and "littoral." The region being examined is "Yoruba" only in the sense of the overwhelming dominance of Yoruba-speaking people in the zone. For, non-Yoruba elements too have played important roles in shaping developments in the zone. It is safe, therefore, to place inhabitants of the zone in a linguistic and cultural continuum, a pan-Yoruba commonwealth, which includes Yoruboid (Itsekiri and Edo) and non-Yoruba peoples as indigenes at both ends of the zone and as residents all over it. We have also demonstrated that the littoral is not a dominant force in the geo-political and economic systems of the Yoruba of Western Nigeria. The littoral zone has been marginal in terms of political influence and state formation. This makes the Yoruba riparian landlubbers in the main.

The second dimension is unpacking the vastness, intricacies and labyrinthine networks of societies within and beyond the Yoruba littoral. This article has attempted to shed light on the patterns of both peaceful and conflictual inter-group relations since the nineteenth century. The exercise has yielded the following general observations about the zone.

The first observation is the profound impact of waves of human migrations on the Yoruba littoral over the centuries. The migrations took place along two axes: a vertical, north-south movement dominated by fellow Yoruba-speaking peoples; and a lateral movement dominated by the Ilaje, Izon, Ogu and Keta (Ewe). The Ilaje are the only truly maritime community among the Yoruba, followed by the waterside Ijebu and Awori. Ilaje colonies all over the Yoruba littoral, and far beyond, are eloquent testimonies and legacies of their unique status in the zone.

Second, fishing has been the driving force behind the lateral movements along the coast. It remains the centre of littoral social and economic life. Fishing is the impetus behind Ilaje, Izon, Ogu and Keta migrations and settlement across the Gulf of Guinea and beyond.

Third, indigenous communities in littoral Yorubaland were subject to political and cultural domination from hinterland power centres, such as Ife, Ijebu and Benin. Such control or influence could be minimal (post-1800 Lagos) or pronounced (Ijebu lagoon communities), depending on changing circumstances. We may note the role of Badagry and Epe as havens or rear bases for political fugitives from Lagos.

Fourth, most Yoruba littoral communities share social and cultural institutions and practices. Among these are the insignia of chieftaincy and traditional institutions, recourse to divination by individuals and communities, com- 
mon festivals, such as Olokun and Okosi, and the pervasive presence of Ayelala.

Fifth, inter-group relations between indigenes and residents of the Yoruba littoral are complex and dynamic. But it can be generalized that ethnic affinity between host communities and fellow Yoruba immigrants, such as between the Awori and Ijebu, on the one hand, and the Ilaje, on the other hand, has mitigated potential conflict and produced generally cordial relationships. In contrast, ethnic diversity has compounded ordinarily tense relations centred on competition over land, fishing and other economic rights. The Ilaje-Izon conflict in southern Ondo State in the 1990s, and recent clashes between the Yoruba and Ogu in the Ajah axis of metropolitan Lagos illustrate this assertion.

Undoubtedly, there are exceptions to these generalizations. Yet, they hold firm given the underpinning, moderating and homogenizing factors of religious affinity, inter-marriage and absorption of immigrant elements into local communities. Hence, it can be concluded that the metaphor of "ayelujara" aptly captures the nuances of the multifaceted relationships among the peoples of littoral Yorubaland. 